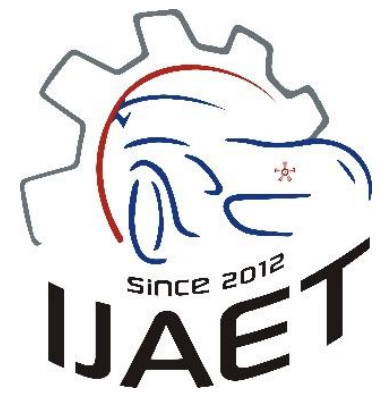

e-ISSN: 2146 - 9067

International Journal of Automotive

Engineering and Technologies

journal homepage:

https://dergipark.org.tr/en/pub/ijaet

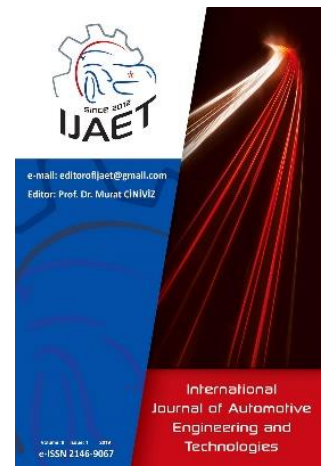

Original Research Article

\title{
The use of waste transformer oil as alternative fuel in a diesel power generator
}

\author{
Abdulkerim Yıldiz ${ }^{1 *}$, Şehmus Altun ${ }^{1}$
}

${ }^{1}$ Department of Mechanical Engineering, Faculty of Engineering and Architecture Batman University, Batman, Turkey.

\begin{abstract}
ARTICLE INFO
* Corresponding author kerimyildiz.7272@gmail.com

Received: May 13, 2019

Accepted: Oct 03, 2019

Published by Editorial Board Members of IJAET

(C) This article is distributed by Turk Journal Park System under the $\mathrm{CC} 4.0$ terms and conditions.
\end{abstract} \begin{abstract}
In this study, waste transformer oil (WTO) was investigated as a fuel candidate for a diesel power generator set in terms of its fuel and combustion characteristics. Kinematic viscosity, which is the most restrictive property of WTO $\left(9.6 \mathrm{~mm}^{2} / \mathrm{s}\right.$ at $\left.40{ }^{\circ} \mathrm{C}\right)$, was measured on different blends with a conventional diesel fuel (in 10, 20, 30, 40, 50, 60, 70, 80, 90 and $100 \%$ by volume) in order to detect the suitable blending ratio to be used in engine without any modification, and to propose some blending strategies to optimize engine performance and emissions. The blended fuels containing WTO up to $50 \%$ with diesel by volume were found to have a viscosity which is within standard value specified for conventional diesel fuels, i.e., $2.0-4.5 \mathrm{~mm}^{2} / \mathrm{s}$ in EN590, and in case 60\% WTO, it agrees with EN14214 $\left(3.5-5.0 \mathrm{~mm}^{2} / \mathrm{s}\right)$ alternative diesel fuel standards. It is also found that a fuel blend containing $20 \%$ WTO and $80 \%$ diesel have a kinematic viscosity and density which are very close to conventional diesel' values. Therefore, WTO was blended with diesel at the rate of $20 \%$ by volume and then tested in a 4 -stroke and 4 -cylinder diesel engine powered generator set under constant speed-variable load conditions. Measured and calculated results were compared with the results of conventional diesel tested under the same conditions. Experimental results showed that specific fuel consumption, $\mathrm{NO}_{\mathrm{x}}$ and unburned $\mathrm{HC}$ emissions reduced when using blended fuel instead of conventional diesel. Cylinder gas pressure was higher for blended fuels than that of conventional diesel while the start of combustion was later in the case of blended fuels.

Keywords: Waste transformer oil; Alternative fuels; Diesel generator; Emissions.
\end{abstract}

\section{Introduction}

Today, studies have been carried out on alternative energy sources in order to meet the increasing energy demand as a result of continually rising energy need. The issues that petroleum having great share in energy consumption has limited reserves and that it is running out and that it leads to increasing amount of environment and air pollution due to its and its derivatives' extreme use directed the researchers to look for alternative energy sources. Numerous waste sources such as waste frying/cooking oils, animal waste fat, waste engine (lubricating) oils, waste plastic and tyres etc. have been investigated to be evaluated as fuel [1-3]. In the studies where waste lubricating oils are searched as alternative to conventional diesel fuels, it is reported that these waste oils 
can be used as fuel readily when process of pyrolysis is applied [4]. In another study, Mani et al. [5] used waste plastic oil in a singlecylinder diesel engine without any modification while an increase in thermal efficiency was reported by Murugan et al. [6] where they used pyrolysis oil, which they obtained from waste automobile tyres by means of pyrolysis method. Similarly, Arpa et al. [7] reported the lower specific fuel consumption when compared to diesel fuel in a single cylinder diesel engine fueled by waste tyre oil.

Among these waste oils, transformer oils as waste oil source are gaining a great importance since these types of oils have high heating value and possess similar properties with diesel fuel, it is of great importance that these oils are evaluated as diesel engine fuels and as fuel additives [8]. The fact that energy sources are limited and that especially the wastes should be regained for the countries which are dependent to foreign countries in terms of energy has always been a significant issue. Therefore, it is very important that these oils should be evaluated again and particularly used instead of petroleum based diesel fuels. It is estimated that the amount of these oils in Turkey is approximately 20000-30000 year/tone [9]. The transformer oils are used in transformers, in some high voltage capacitors, in florescent lamps, in high voltage switches and high voltage circuit breakers. The basic functions of isolating oils are cooling the parts warming up due to heat transfer and providing electrical isolation and suppressing arcs occurring between electric components and protecting the surfaces they contact [10]. Mineral oils which are composed of hydrocarbons of paraffinic, aromatic or naphthenic character that are obtained by the fractional distillation of crude petroleum, synthetic esters and silicone oils are traditionally used as the raw material for the production of transformer oils [11]. However, after long use, the transformer oil becomes unusable because high temperatures and moisture act, then it is disposed of, and it also contains some other substances such as copper, paint, varnish and oxygen, which are responsible for degradation. When a transformer is subjected to thermal and electrical stresses in an oxidizing atmosphere, it gradually loses its stability and becomes decomposed and oxidized, and its acidity increases, and finally, it begins to produce mud [11]. The filtration, contact and rafination methods could be applied to improve or regain these oils, however, rafination can only be carried out in an oil producing refinery and it is considerably expensive [10]. Therefore, in filtration method, the oil taken from the bottom valve of electrical equipment is heated, and then it is filtrated to separate particles and solid substances. The oil is poured down into the boiler from the top. In this way, the oil is circled a few times (circulation). After the circulation process is completed, the oil is passed through fuller clay and similar substances; thus, the polar dirt present in the oil in solution form is cleaned. Finally, water and gases present in the oil in solution form are disposed after being passed through oil purifier. And in contact method, the improvement level depends on the amount of clay in the oil, and it is determined according to pollution level. Through this method, it is possible to clean great amount of dirty oil.

Transformer oil has been explored by numerous researchers to determine the possibility of utilizing the transformer oils as an alternative fuel in CI engines. For example, Behera ve Murugan [12] evaluated the transformer oil and its blends with diesel as fuel in a DI diesel engine, and an increase in efficiency with a drop in smoke values was reported for transformer oil and blended fuels compared to diesel. Salmani et al., [13] reported that in their studies where they utilized used transformer oil and diesel fuel blends as fuel, the thermal efficiency was approximately $15 \%$ higher compared to diesel fuel when blended fuel was used. Behera [14] reported that the power output for transformer oil was higher than that of diesel. In another study, Yadav et al., [15] pretreated waste transformer oil by using concentrated sulfuric acid and then subjected it to base-catalysed transesterification, and investigated the effect of engine modification on the use of a high viscous fuel like this fuel. In another study, Qasim et al. [16] studied the combustion characteristics of a diesel engine operated with blends of transesterified waste transformer oil and waste canola oil methyl esters with petroleum diesel. On the other hand, the usage of generator sets, an important application field of diesel engines, becomes prevalent as well. Although there are studies related to the use of waste transformer 
oils as diesel engine fuels in the literature, it presents great importance that these oils should be used as fuels in diesel powered generator sets as well. Therefore, this study aimed to investigate the feasibility of utilizing waste transformer oil as a fuel in a diesel generator set. For this purpose, waste transformer oils' using conditions in terms of fuel properties, blending scenarios and combustion characteristics were studied so that these oils could be evaluated as alternative diesel engine fuels after the fuel properties of waste transformer oil obtained from transformers located in electric transmission stations were improved by means of filtration method.

\section{Materials and Methods}

\subsection{Waste transformer oil and properties}

Waste transformer oil was obtained from Turkish Electricity Transmission Corporation Batman Regional Directorate located in Batman, Turkey. As a result of the first observations, it was understood that the oil contained water and sediment. The oil was filtrated in Refinery and Petro-Chemical laboratory in Batman University, and then heated for a while at $100-110{ }^{\circ} \mathrm{C}$. The oil properties, given in Table 1, were determined in the fuel analysis laboratory of Turkish Petroleum Refinery Corporation (TÜPRAŞ). In Table 1, these properties were compared with EN590 diesel fuel standard values (EN590:2009) and conventional diesel. Also, accuracy is given for devices used in determination fuel characteristics.

When waste transformer oil properties given with EN590 diesel fuel standards in Table 1 are examined, it is seen that density and viscosity values of the oil is much higher than standard values and diesel fuels'. Especially, the fact that its viscosity is high makes it difficult to be used as fuel in pure form. However, that its flash point is high makes it a reliable fuel while transporting and storing. When compared to the standards of EN590, it is seen that it has a good CFPP and low water content (after the application of pre-treatment process). Nevertheless, while high sulphur content makes a negative situation in terms of emissions, it is anticipated that it has a better lubricating property compared to diesel fuels. That its cetane index is above the standard value turns out to be a positive property in terms of combustion in engine.

Table 1 Comparison of waste transformer oil (WTO) with conventional diesel and EN590

\begin{tabular}{lcccc}
\hline Property & WTO & Conventional diesel & EN 590 & Accuracy \\
\hline Density $\left(\right.$ at $\left.15{ }^{\circ} \mathrm{C}, \mathrm{kg} / \mathrm{m}^{3}\right)$ & 885 & 840 & $820-845$ & 0.1 \\
Kin. Viscosity $\left(\mathrm{at} 40^{\circ} \mathrm{C}, \mathrm{mm}^{2} / \mathrm{s}\right)$ & 9.637 & 3.18 & $2.0-4.5$ & 0.001 \\
Flash Point $\left({ }^{\circ} \mathrm{C}\right)$ & $120^{+}$ & 60.5 & Min. 55 & 0.5 \\
CFPP $\left({ }^{\circ} \mathrm{C}\right)$ & -17 & -14 & $-15+5$ & 0.1 \\
Cetane Index & 48.67 & 55 & 46 & - \\
Lower Heating Value $(\mathrm{kJ} / \mathrm{kg})$ & 45507 & 42850 & - & 1.0 \\
Sulphur content $(\mathrm{ppm})$ & 24.4 & 9.8 & Max10 & 0.1 \\
Water content $(\mathrm{ppm})$ & 26 & 156,4 & Max200 & 0.01 \\
\hline
\end{tabular}

Table 2 Viscosity and density values of fuel blends

\begin{tabular}{ccc}
\hline $\begin{array}{c}\text { WTO } \\
\text { (by volume, \%) }\end{array}$ & $\begin{array}{c}\text { Kin. Viscosity } \\
\left(\mathrm{mm}^{2} / \mathrm{s}\right)\end{array}$ & \begin{tabular}{c} 
Density $\left(\mathrm{kg} / \mathrm{m}^{3}\right)$ \\
\hline 0
\end{tabular} \\
2.616 & 832 \\
10 & 2.865 & 832 \\
20 & 3.21 & 838 \\
30 & 3,612 & 844 \\
40 & 4.054 & 851 \\
50 & 4.599 & 857 \\
60 & 5.329 & 863 \\
70 & 6.02 & 866 \\
80 & 7.107 & 874 \\
90 & 8.313 & 879 \\
\hline
\end{tabular}

Due to especially high viscosity value of waste transformer oil, its blend form is found to be suitable for using because of the difficulty to use it as a fuel directly. Therefore, the waste transformer oil was diluted by adding conventional diesel fuel into it at some certain proportions; and it was decided which blends would be used as test fuel by establishing distillation, viscosity and density values of these fuel blends. The kinematic viscosity (at $40^{\circ} \mathrm{C}$ ) and density $\left(\right.$ at $15^{\circ} \mathrm{C}$ ) values are given in Table 2 , and these blends were prepared by adding $10 \%, 20 \%, 30 \%, 40 \%, 50 \%, 60 \%, 70 \%, 80 \%$ and $90 \%$ of waste transformer oil into the diesel 
fuel volumetrically in Refinery and PetroChemistry Fuel Analysis Laboratory in Batman University.

As can be seen in Table 2, value rises occurred in viscosity and density after waste transformer fuel was added to diesel fuel. Viscosity values remained within EN590 standard values (4.5 $\mathrm{mm}^{2} / \mathrm{s}$ ) until the blend was at $50 \%$, but after this proportion it started to exceed out of this standard value. A similar case was witnessed for density values; however, standard values were attained with $30 \%$ blend. In addition to this, the viscosity and density values obtained in the case of adding waste transformer oil until $60 \%$ remain within the standard values related with alternative oil in diesel engines (for biodiesel the specified density in EN14214 860-900 kg/m 3 and for kinematic viscosity $3.5-5.0 \mathrm{~mm}^{2} / \mathrm{s}$ ). Moreover, a blend of 20\% WTO and $80 \%$ diesel is found to have a kinematic viscosity and density which are very close to conventional diesel' values. Therefore, it is decided to test this fuel blend in diesel powered generator.

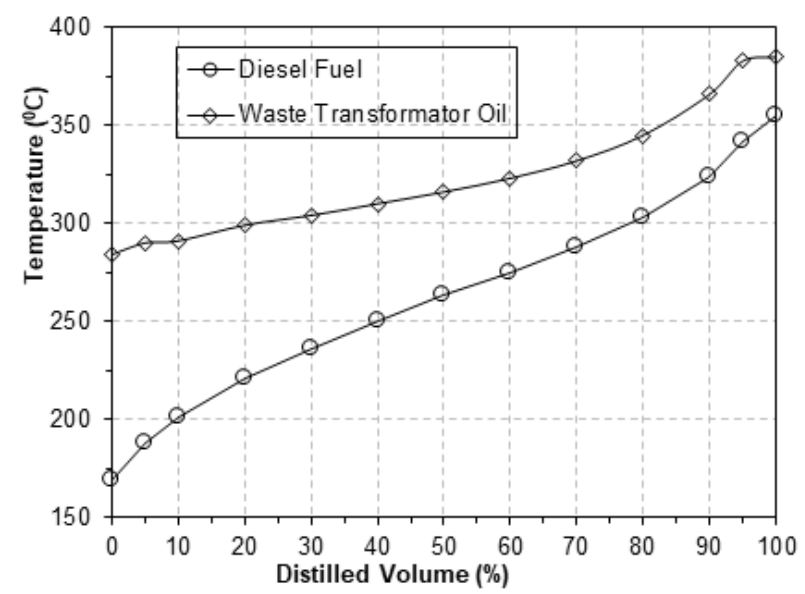

Figure 1 Distillation temperature of waste transformer oil and diesel fuel

In Figure 1, distillation temperatures of waste transformer oil and diesel fuel are seen. As seen in the figure, the initial boiling point of waste transformer oil is higher than that of diesel. While diesel starts to boil at $160^{\circ} \mathrm{C}$, the temperature is $284^{\circ} \mathrm{C}$ for waste transformer oil. The vaporizing temperatures of $10 \%, 50 \%$ and $90 \%$ for waste transformer oil were $291^{\circ} \mathrm{C}, 316$ ${ }^{\circ} \mathrm{C}$ and $366^{\circ} \mathrm{C}$, respectively; on the other hand, for the same proportions the temperatures were $201^{\circ} \mathrm{C}, 263^{\circ} \mathrm{C}$ and $324^{\circ} \mathrm{C}$ for diesel fuel. The final boiling point was $385^{\circ} \mathrm{C}$ for waste transformer oil and $355^{\circ} \mathrm{C}$ for diesel oil. As clearly can be seen, final boiling point of waste transformer oil is higher than that of diesel. Although initial boiling point of waste transformer oil is high, it is an indication that the initial start of engine with fuel blends will be more difficult than conventional diesel engine. However, that distillation curve of waste transformer oil is more homogenous will lead to lower unburnt $\mathrm{HC}$ occurrence. Therefore, it is anticipated that lower unburnt $\mathrm{HC}$ occurs in blend fuels compared to conventional diesel fuel.

\subsection{Engine experiment set}

Test fuels were a blended fuel and conventional petroleum based diesel fuel. Blended fuel was prepared by adding waste transformer oil into petroleum origin diesel fuel at a ratio of $20 \%$ volumetrically while conventional diesel was supplied from a local petrol station in Batman. These fuels were tested in diesel engine powered generator set shown in Figure 2, which is consist of a $230 / 400 \mathrm{~V}$ brushless synchronic type $1500 \mathrm{rpm}(50 \mathrm{~Hz}), 22 \mathrm{kVA}$ (stand-by), 20 $\mathrm{kVA}$ (prime) alternator and a 4 cylinder and 4 stroke direct injection, naturally aspirated and water cooled diesel engine, and also the necessary devices such as fuel consumption, water, oil and exhaust temperature measuring gadgets and an exhaust gas measuring device and in-cylinder pressure measuring system. The engine specifications are given in Table 3. In addition to all these, there is an inner ampere meter and a volt-meter so that the energy that the generator produces can be measured. In order that the engine will be loaded, electrical resistances consuming electricity generated by alternator are used in the test. The engine load was controlled by utilizing resistances with different capacities. After the maintenance of engine was done, the engine was operated with the fuel used in the test in question before the test so that the engine could be stabilized before starting to gather data. After the engine was stabilized, tests were performed under three different engine loads with $1500 \mathrm{rpm}$ using each test fuel at a time. The tests were carried out at constant load and engine speed and the average of the five values for each test were taken. The reason for keeping the engine load and speed constant is that the comparisons can easily be made when other conditions are changed. The mean values obtained and depicted in figures. 
Table 3 Specifications of the engine

\begin{tabular}{ll}
\hline \multicolumn{1}{c}{ Specification } & \multicolumn{1}{c}{ Descriptions } \\
\hline Fuel injection & Direct injection \\
Power output & $18 \mathrm{~kW}$ @ 1500 rpm \\
Intake & Naturally aspirates \\
Bore x stroke & $85 \times 100 \mathrm{~mm}$ \\
Displacement & $2400 \mathrm{~cm}^{3}$ \\
Number of cylinder & 4 \\
Compression ratio & $17: 1$ \\
\hline
\end{tabular}

The fuel consumption was measured in mass via electronic balance with $1 \mathrm{~g}$ sensitivity and digital chronometer. In order that the engine performance could be evaluated, the specific fuel consumption and effective output values were calculated using the measured output power and fuel consumption and heat values of fuels. Specific fuel consumption (sfc) and thermal efficiency were calculated by using following formulas;

$b e=\frac{B}{P e} * 3600$

where: be: specific fuel consumption $(\mathrm{g} / \mathrm{kWh})$

B: fuel consumption $(\mathrm{g} / \mathrm{s})$

Pe: power output $(\mathrm{kW})$

$\eta_{e}=\frac{3600}{b e^{*} H u}$

$\eta_{e}=$ effective efficiency $(\%)$

be $=$ specific fuel consumption $(\mathrm{kg} / \mathrm{kWh})$

$\mathrm{Hu}=$ lower heating value $(\mathrm{kJ} / \mathrm{kg})$

Gas analysis device with the brand of CAPELEC CAP-3200 was used for exhaust gas analyses. Optrand brand D33294-Q model fiber optic pressure sensor analysis device (with sensitivity $1.35 \mathrm{mV} / \mathrm{psi}$ ) was used for in-cylinder gas pressure measurement. The crankshaft angle was established by means of magnetic speed sensor. The magnetic speed sensor was mounted in such a way that it could produce signals on top dead center (TDC) by using the place determined for TDC on the crankshaft pulley. The signals coming from pressure sensors were transferred to a computer by means of signal conditioner and data collecting card, and these data was realized with the help of FebriS combustion analysis software. In-cylinder pressure data was collected by averaging 100 engine cycles. Heat release was analyzed with pressure data obtained from a cylinder whose volume was known utilizing the first law of thermo-dynamics and ideal gas equation. The accuracy of the test devices was given in Table 4.

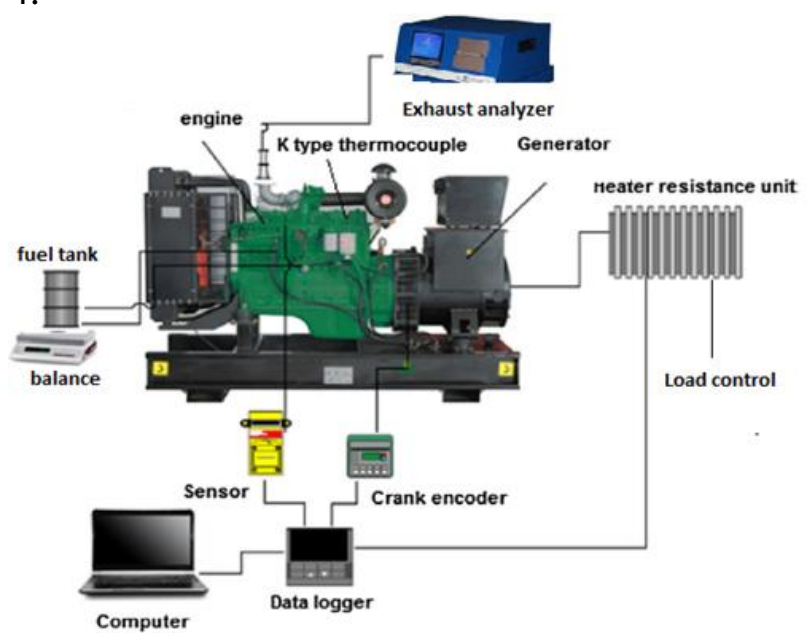

Figure 2 Schematic view of experimental setup

Table 4. Measuring range and accuracy of the test devices

\begin{tabular}{lll}
\hline Measurement & $\begin{array}{l}\text { Measurement } \\
\text { range }\end{array}$ & Accuracy \\
\hline Cylinder pressure & $0-200 \mathrm{bar}$ & $\leq \pm 0.5 \%$ \\
Speed & $0-12000 \mathrm{rpm}$ & $\pm 0.1 \%\left[^{\circ}\right]$ \\
Fuel consumption & $0.5-3000 \mathrm{~g}$ & $\pm 0.5 \mathrm{~g}$ \\
Exhaust gas & -32 to $400^{\circ} \mathrm{C}$ & $\pm 1 \%$ \\
temperature & & \\
$\mathrm{HC}$ & $0-20000 \mathrm{ppm}$ & $\pm 1 \mathrm{ppm}$ \\
$\mathrm{CO}$ & $0-20 \%$ & $\pm 0.1 \%$ \\
$\mathrm{CO}$ & $0-15 \%$ & $\pm 0.001 \%$ \\
$\mathrm{O}_{2}$ & $0-21.7 \%$ & $\pm 0.01 \%$ \\
$\mathrm{NO}_{\mathrm{x}}$ & $0-5000 \mathrm{ppm}$ & $\pm 1 \mathrm{ppm}$ \\
\hline
\end{tabular}

\section{Results and Discussion}

In this part of the paper, the experimental results obtained for diesel and blended fuels are presented with a focus on the combustion and exhaust emission characteristics.

\subsection{Combustion characteristics}

For test fuels, the change in cylinder gas pressure and rate of heat release (RoHR) values are shown in Figs. 3, 4 and 5. For 3.6, 7 and 10.2 $\mathrm{kW}$ load, peak pressure was measured as 65,54 , 72,80 and 78.32 bar for diesel while it was $65,07,74,01$ and 81,8 bar for blended fuel. As seen, by adding waste oil to diesel a slight increased maximum pressure values occurred due to higher energy content and kinematic viscosity. At $10.2 \mathrm{~kW}$, peak pressure values were obtained as $9 \mathrm{CA}$ after top dead center for both fuels. The occurrence of the ignition of blended fuel is at $1 \mathrm{CA}$ earlier than that of diesel operation at full load with help of a slight high cetane number. In Figs. 3, 4 and 5, for all test 
fuels, the heat release is seen to be around negative value before it starts to rise. The reason of this decline is considered to be the heat loss from combustion environment due to fuel injection into combustion chamber and its evaporation. This stems from heat shrinkage in the cylinder for vaporization of fuel sprayed. With an increase in load, released heat is also increased for both fuels tested, as seen figs. Under low load conditions i.e., 3,6 kW, peak heat release rate was $47,45 \mathrm{~J} /{ }^{0}$ while it was calculated for blended fuel as $45,6 \mathrm{~J} /{ }^{0}$. When load increased to $7-10,2 \mathrm{~kW}$, respectively, RoHR was calculated as $58-66 \mathrm{~J} /{ }^{0}$ for diesel and $61,53-73,01 \mathrm{~J} /{ }^{0}$ for blended fuel. These values were obtained at $4 \mathrm{CA}$ after top dead center for both fuels. As can be understood from these values, there was a slight increase in maximum heat release for blended fuel at higher loads while at low load conditions a slight reduction was observed.

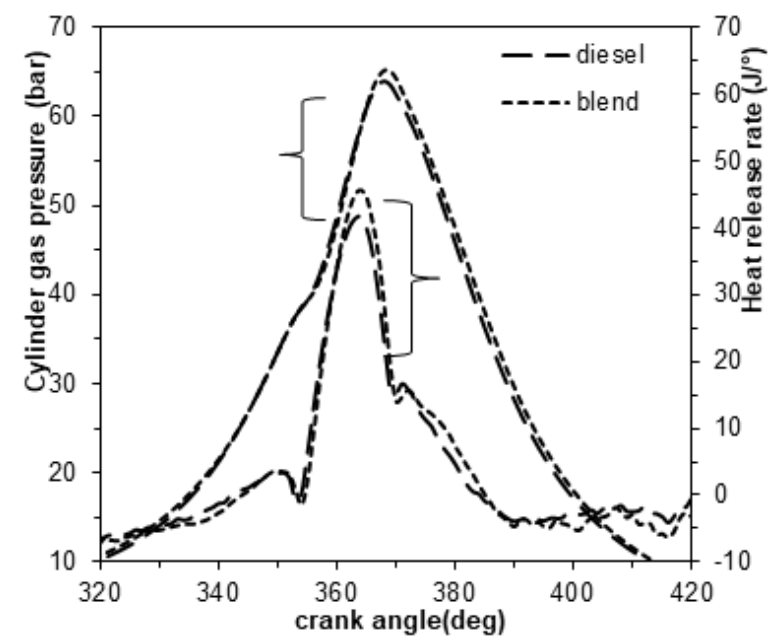

Figure 3. Cylinder gas pressure and heat release against crank angle for diesel and blended fuel at $3.6 \mathrm{~kW}$ and

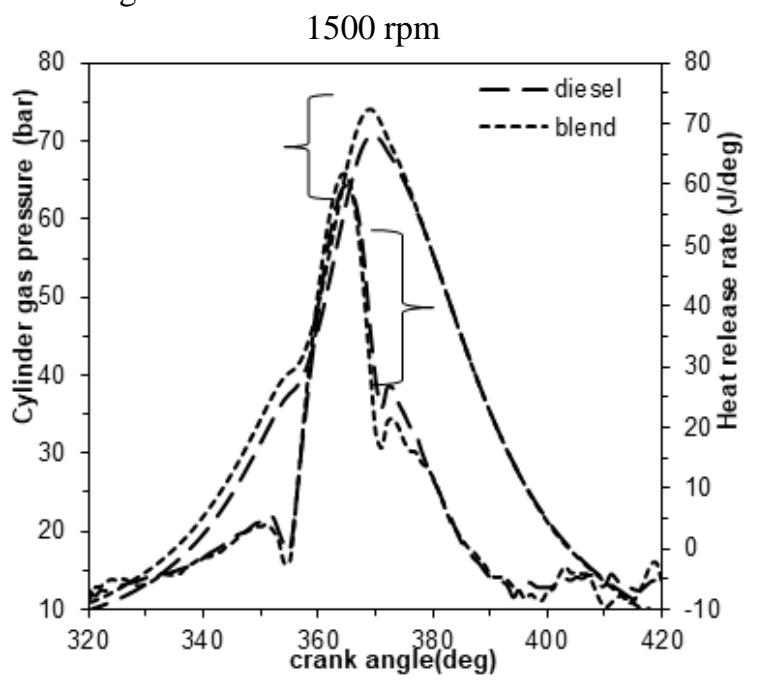

Figure 4. Cylinder gas pressure and heat release against crank angle for diesel and blended fuel at $7 \mathrm{~kW}$ and 1500 rpm

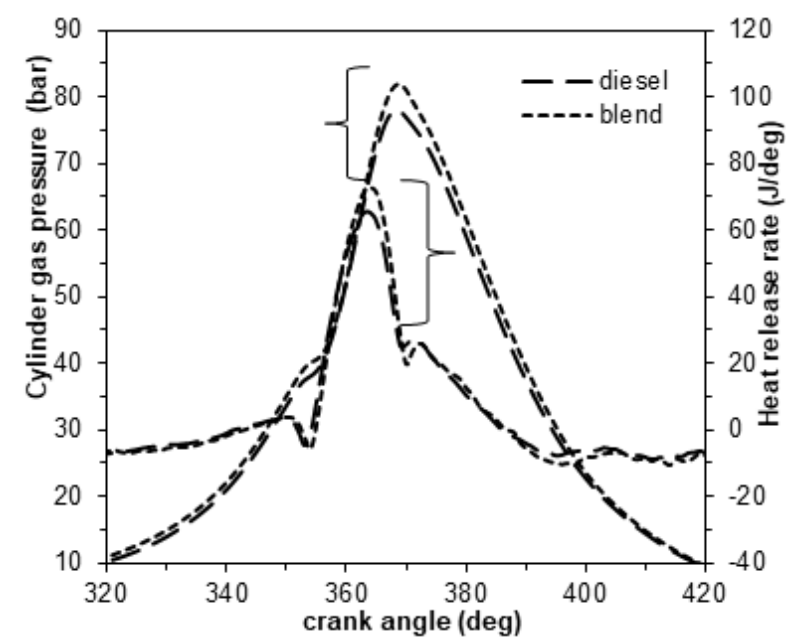

Figure 5. Cylinder gas pressure and heat release against crank angle for diesel and blended fuel at $10.2 \mathrm{~kW}$ and $1500 \mathrm{rpm}$

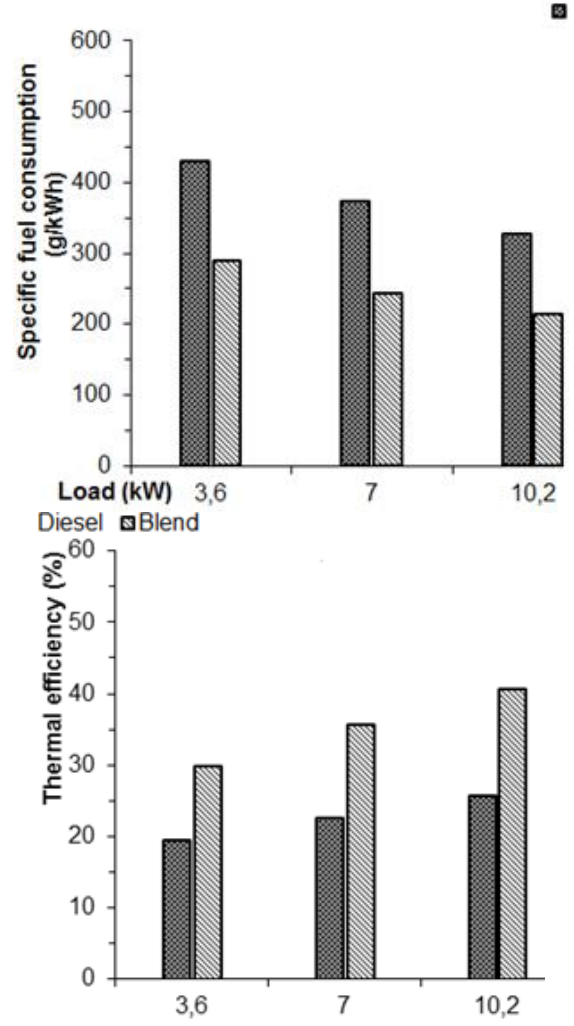

Figure 6. specific fuel consumption and thermal efficiency versus load for diesel and blended fuel

\subsection{Engine performance}

Under the constant load and speed operating conditions, which were adjusted regardless of test fuels, the specific fuel consumption ( $\mathrm{sfc}$ ) is shown on the left side of Fig. 6 as decreased for fuel blend compared to conventional diesel, mainly thanks to the increase in the energy content. Up to $14.7 \%$ reduction in sfc is reported in the study of Raj Yadav et al., [17] for waste transformer oil-diesel blends. As presented in Table 1, waste transformer oil has a higher heating value than conventional diesel fuel. 
Similarly, lower sfc with $20 \%$ waste transformer oil containing fuel blend than diesel fuel is reported by Nabi et al., [8]. This reduction in fuel consumption for blended fuel clearly reflects an improvement in thermal efficiency, which is shown in right side of Fig.6. The improved thermal efficiency when waste transformer oil-diesel blends are used is reported by other researchers $[13,15]$.

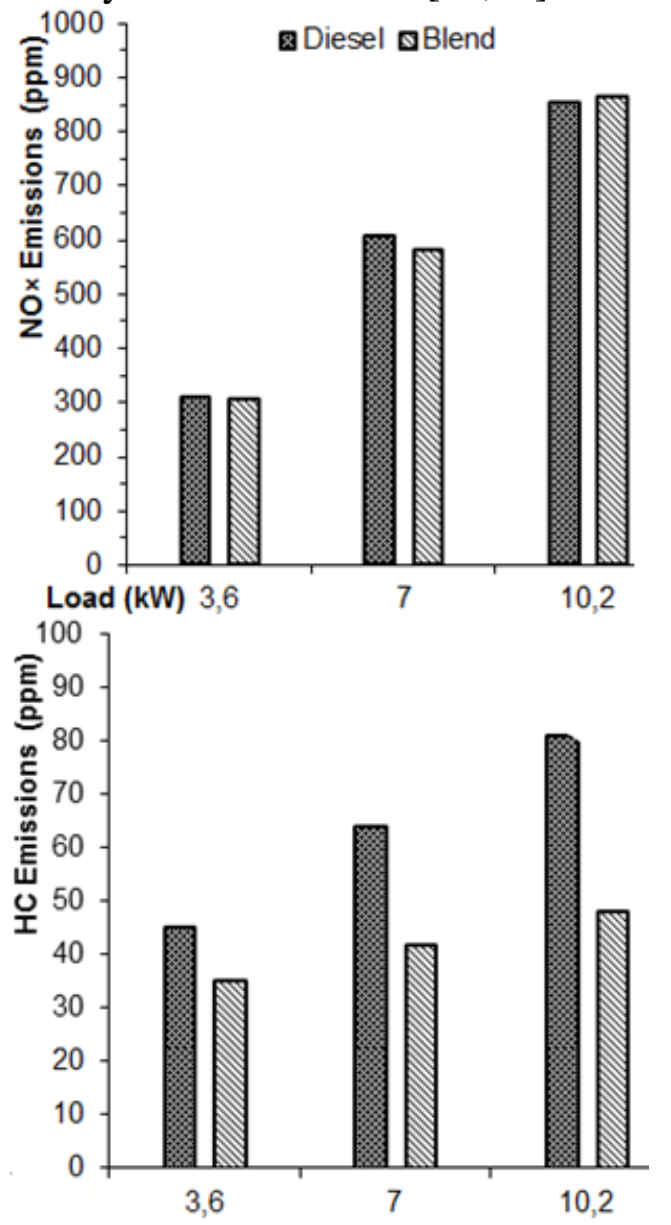

Figure 7. $\mathrm{NO}_{\mathrm{x}}$ and $\mathrm{HC}$ emissions versus load for diesel and blended fuel

\subsection{Gaseous emissions}

The change in $\mathrm{NO}_{\mathrm{x}}$ emissions with engine load for test fuels is given in Figure 7. While the highest $\mathrm{NO}_{\mathrm{x}}$ was obtained at $10.2 \mathrm{~kW}$ for all fuels, the lowest value was obtained at $3.6 \mathrm{~kW}$ load conditions. However, while the highest $\mathrm{NO}_{\mathrm{x}}$ was measured at $3.6 \mathrm{~kW}$ as $310 \mathrm{ppm}$ in diesel use, the lowest value was measured at 305 $\mathrm{ppm}$ in the use of blended fuel. At medium load, the highest $\mathrm{NO}_{\mathrm{x}}$ was obtained with diesel use while $\mathrm{NO}_{\mathrm{x}}$ was slightly higher under the load of $10,2 \mathrm{~kW}$ with the use of blended fuel than diesel. In general, $\mathrm{NO}_{\mathrm{x}}$ emissions are about the same for all load conditions. On the other hand, unburnt $\mathrm{HC}$ emissions are seen as increased with the increase in engine load in the right side of Fig.7. In all loads, unburnt $\mathrm{HC}$ emissions are measured as higher for conventional diesel than blended fuel. Under the load condition of $3.6 \mathrm{~kW}$, the unburnt $\mathrm{HC}$ emissions for blended fuel turned out to be lower by about $22 \%$ compared to conventional diesel. Under the load conditions of $7 \mathrm{~kW}$ and $10.2 \mathrm{~kW}$, the unburnt $\mathrm{HC}$ emissions for blended fuel turned out to be approximately lower by $34.3 \%-40.7 \%$, respectively. Reasonably, the advancement in combustion when blended fuel is used with the help of homogenous distillation temperature and the enhanced fuel properties may lead to decreasing $\mathrm{HC}$ emission.

\section{Conclusions}

Waste transformer oil was used as fuel by blending it with diesel fuel in the proportions of $20 \%$ by volume. Since the properties of this blend were close to those of diesel fuel, it was tested in a diesel engine powered generator without any engine modification and any difficulties. It was established that the engine performance values of blended fuel turned to be higher than that of diesel fuel. In engine tests, while lower or close values were obtained in $\mathrm{NO}_{\mathrm{x}}$ emissions in exhaust gases compared to diesel fuel, at the end of $\mathrm{HC}$ emission measurements, it was observed that these emissions were a lot lower than that of diesel fuel. Consequently, waste transformer oil (WTO) may be utilized as alternative fuels in different blends volumetrically without any extra cost only by using the filtration method. In this study, it was preferred to use waste transformer oil in blends with diesel fuel since it is difficult to use WTO directly due to its high viscosity. When particularly low fuel consumption values, which are obtained for test blend ratio, are taken into consideration, it presents great significance that the viscosity problem should be solved and then it should be tested directly. In addition, due to the decrease in unburnt $\mathrm{HC}$ emissions, it will provide contributions waste transformer oils to be evaluated as alternative fuels; and it will provide opportunities to compare this blended fuel with biodiesel fuels widely used in diesel engines.

\section{References}

1. F. Yaşar, Ş. Altun. The effect of 
microalgae biodiesel on combustion, performance, and emission characteristics of a diesel power generator, Thermal Science, 22(3) (2018) pp.1481-1492.

2. Chandran, M., Tamilkolundu, S., Murugesan, C. Investigation of the performance, combustion parameters and emissions analysis on DI engine using two staged distilled waste plastic oil-diesel blends, Thermal Science, 22(3) (2018), pp.1469-1480.

3. Ertuğrul, Ö, Altun, Ş. "Determining optimal artificial neural network training method in predicting the performance and emission parameters of a biodiesel-fueled diesel generator". International Journal of Automotive Engineering and Technologies 7 (2018): 7-17.

4. Uyumaz, A, aksoy, F, mutlu, İ, akbulut, F, yilmaz, E . "The Pyrolytic Fuel Production from Nutshell-Rice Husk Blends and Determination of Engine Performance and Exhaust Emissions in a Direct Injection Diesel Engine". International Journal of Automotive Engineering and Technologies 7 (2018): 134141.

5. Mani, M., Subash, C., Nagarajan, G., Performance, emission and combustion characteristics of a DI diesel engine using waste plastic oil, Applied thermal engineering, 29, (2009), pp.2738-2744.

6. Murugan, S., Ramaswamy, M.C., Nagarajan, G. The use of tyre pyrolysis oil in diesel engines, Waste Management, 28, (2008), pp.2743-2749.

7. Arpa, O, Yumrutas, R., Argunhan, Z., Experimental investigation of the effects of diesel-like fuel obtained from waste lubrication oil on engine performance and exhaust emission, Fuel Processing Technology, 91, (2010), pp.1241-1249.

8. Nabi, M.N., Akhter, M.S., Rahman, M.A. Waste transformer oil as an alternative fuel for diesel engine, Procedia Engineering, 56, (2013), pp.401-406.

9. Anonim, 2011, T.C. Milli Eğitim Bakanlığı Megep, Atık yağlar modülü Yayınlar1, 850CK0098. Ankara, 2011. (In Turkish).

10. Sezer, M., Trafo bakımı ve yalıtım yağı, Çağdaş yayınevi, Balıkesir, Türkiye, 2009. [In Turkish].

11. Saidulu, G.S., Dattatreya, G., Performance evaluation and emission characteristics of a waste transformer oil as an alternative fuel for diesel engine, International Journal of Emerging Trends \& Technology in Computer Science, 4, (2015), 2, pp.33-41.

12. Pritinika, B., Murugan, S., Combustion, performance and emission parameters of used transformer oil and its diesel blends in a DI diesel engine, Fuel, 104, (2013), pp.147-154.

13. Salmani, M.H., Sharma, R.C., Kumar, H., Dhingra, M., Effect of Used Transformer Oil on Efficiency of Compression Ignition Engine, International Journal for Technological Research in Engineering, 2, (2015), 7, pp.786791.

14. Pritinika, B., Experimental Studies on Utilization of Used Transformer Oil as an Alternative Fuel in a DI Diesel Engine, Ph. D. thesis, National Institute of Technology Rourkela, India, 2013.

15. Yadav, S. P. R., Saravanan, C. G., Kannan, M., Influence of injection timing on DI diesel engine characteristics fueled with waste transformer oil, Alexandria Engineering Journal, 54 (2015), 4, pp.881-888.

16. Qasim, M., Ansari, T.M., Hussain, M., Combustion, Performance, and Emission Evaluation of a Diesel Engine with Biodiesel Like Fuel Blends Derived from a Mixture of Pakistani Waste Canola and Waste Transformer oils, Energies, 10, (2017), pp.1023.

17. Raj Yadav, S.P., Saravanan, C.G., Vallinayagam, R., Vedharaj, S., Roberts, W.L., Fuel and engine characterization study of catalytically cracked waste transformer oil, Energy Conversion and Management, 96, (2015), pp.490-498. 